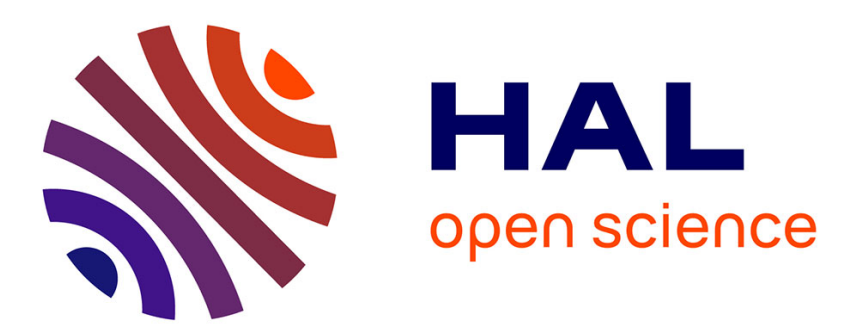

\title{
Impact of load characteristics on photovoltaic PV system with P\&O MPPT controller.
}

Ahmed Saidi, Cherif Benoudjafer, Benachaiba Chellali, Samia Benyahia

\section{To cite this version:}

Ahmed Saidi, Cherif Benoudjafer, Benachaiba Chellali, Samia Benyahia. Impact of load characteristics on photovoltaic PV system with P\&O MPPT controller.. International Meeting on Advanced Technologies in Energy and Electrical Engineering, Nov 2018, Fés, Morocco. hal-01941556

\section{HAL Id: hal-01941556 https://hal.science/hal-01941556}

Submitted on 1 Dec 2018

HAL is a multi-disciplinary open access archive for the deposit and dissemination of scientific research documents, whether they are published or not. The documents may come from teaching and research institutions in France or abroad, or from public or private research centers.
L'archive ouverte pluridisciplinaire HAL, est destinée au dépôt et à la diffusion de documents scientifiques de niveau recherche, publiés ou non, émanant des établissements d'enseignement et de recherche français ou étrangers, des laboratoires publics ou privés. 


\title{
Impact of load characteristics on photovoltaic PV system with P\&O MPPT controller.
}

\author{
${ }^{1}$ *SAIDI Ahmed., ${ }^{1}$ Benoudjafer Cherif., ${ }^{1}$ Chellali Benachaiba., ${ }^{2}$ Benyahia Samia \\ 1ahmedsaidi@outlook.com, Tahri Mohamed university Béchar, Algeria \\ ${ }^{2}$ Badji Mokhtar university Annaba, Algeria
}

\begin{abstract}
In the last decade, the use of renewable energy resources instead of fossil fuels pollutants has increased exponentially. Photovoltaic energy generation is ever more important as a renewable resource since it does not cause in fuel costs, pollution, maintenance, and emitting noise compared to other renewable resources as more accessibility of solar irradiation.
\end{abstract}

This paper presents impact load characteristics on MPPT controller of R, RC, RL and RLC circuit load with Perturb and Observe Maximum Power Point Tracking (MPPT) algorithm for a stand-alone photovoltaic system and sees the comparison of each circuit load on the system and the algorithm of control. The different results of power, voltage and current are discussed and shown that the inductor it has a capital effect on Maximum power point (MPP) and system in general. The simulation results and a comparative analysis are discussed in this paper.

\section{Simulation and results}

In this part, the PV system simulation is realized to research the effects of the sliding mode MPPT controller parameters on the system performance. The PV system presented by Fig. 1

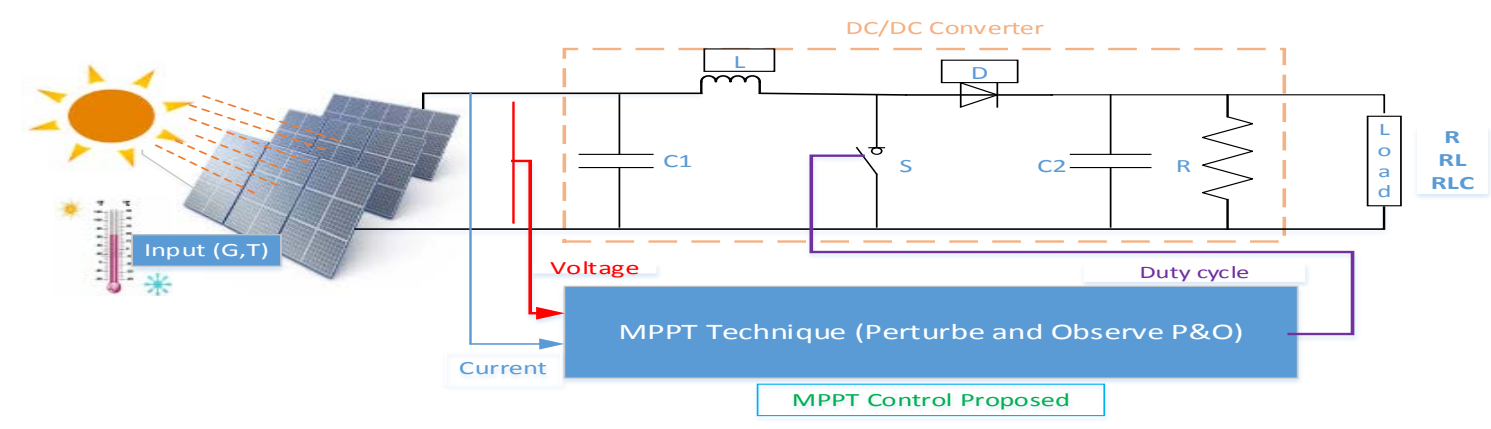

Figure 1. Proposed Photovoltaic PV system 
IMAT3E' 18

International Meeting on Advanced Technologies in Energy and Electrical

Engineering

In the following, we will discuss the reliability of the MPPT controller based on Perturb and Observe. So for the evaluation of the proposed MPPT controller performance, simulation results are presented in four subsections[1]-[3]:

1. The reliability of the MPPT controller with changing irradiations,

2. The robustness of the MPPT controller against load variations,

3. The reliability of the MPPT controller with simultaneous change of irradiation and load.

\section{R, RL, RC loads:}

We suppose that the irradiations trajectory mentioned takes this form: it decreases irradiation from 1000 to 800 to $600 \mathrm{~W} / \mathrm{m} 2$ in steps of 200 units and we consider that the temperature is a constant $\left(T=25^{\circ} \mathrm{C}\right)$.

The simulation results show that the characteristic load it has a major effect on MPPT, moreover on Perturb and Observe controller.

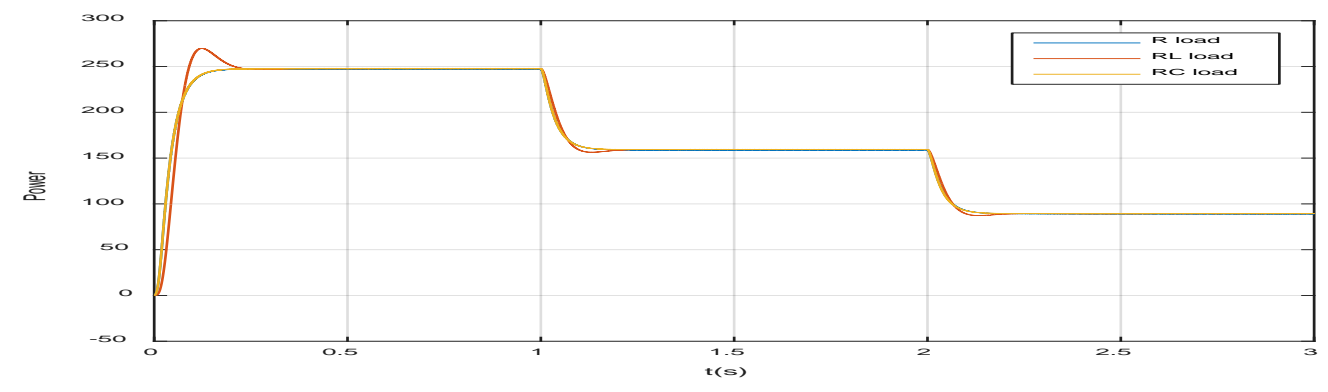

Figure 2. Output Power of the solar array

\section{RL, RC, RLC loads:}

This simulation is presented to mention the principal factor in the exceeding and the effect of each element of the charge and its effect on the MPPT controller

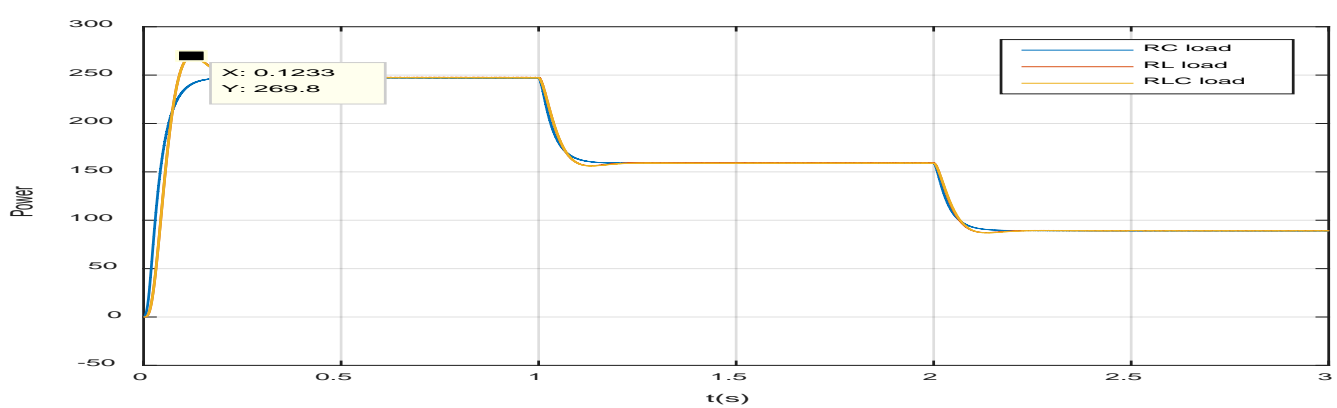

Figure 3. Output Power of the solar array 
The simulation of the PV array with a deference load R, RC, RL, and RLC shows the negative effect of the inductor load on the maximum power point of the system and the response of MPPT controller, and we can see that the load has a large importance to determine the maximum power point and a direct influence on the MPPT controller.

So the proposed siding mode controller under variable irradiations and characteristic load conditions are exhibiting an accurate control signal. This is clear if we examine Fig.2 and 3 , the sliding controller is adjusting in every case of the corresponding value of the control signal that extracts the maximum power from the PV panel. In Fig. 3, the proposed Perturb and Observe controller is proving its robustness against load change. load.

Table 1 presents typical peak of Power, voltage, and current for each characteristic circuit

\begin{tabular}{|l|l|l|l|}
\hline Load & $\begin{array}{l}\text { Typical peak } \\
\text { power (P) [W] }\end{array}$ & $\begin{array}{l}\text { The voltage at peak } \\
\text { power (VMPP) [V] }\end{array}$ & $\begin{array}{l}\text { Current at peak power (IMPP) } \\
{[\mathbf{A}]}\end{array}$ \\
\hline R & 249 & 87.74 & 2.81 \\
\hline RC & 249.12 & 86.37 & 2.83 \\
\hline RL & 269.8 & 94.99 & 2.91 \\
\hline RLC & 269.8 & 94.99 & 2.91 \\
\hline
\end{tabular}

The techniques have been implemented in standalone PV system as shown in the simulation model to study their individual efficiency and response towards the variation in solar irradiance and load. The comparison proves that the proposed MPPT technique has better tracking ability and speed of response towards the PV system irrespective of irradiance and load variation. Moreover, the optimal operating point does not oscillate around the MPP in case of R and RC Load. But in the case of RL and RLC load overtaking time to change irradiation caused by inductive.

\section{Références}

[1] A. Saidi, B. Cherif, and B. Chellali, "Fuzzy intelligent control for solar/wind hybrid renewable power system,” EEA - Electroteh. Electron. Autom., vol. 65, no. 4, 2017.

[2] S. Ahmed, C. Benoudjafer, and C. Benachaiba, "MPPT Technique for Standalone Hybrid PV-Wind Using Fuzzy Controller," in Artificial Intelligence in Renewable Energetic Systems, 2018, pp. 185-196.

[3] W. El-Baz, P. Tzscheutschler, and U. Wagner, "Day-ahead probabilistic PV generation forecast for buildings energy management systems,” Sol. Energy, vol. 171, no. June, pp. 478-490, 2018. 